\title{
Eco-Efficiency Indicators for Urban Transport
}

\author{
Patrick Moriarty, Stephen Jia Wang* \\ Department of Design, Monash University-Caulfield Campus, Melbourne, Australia \\ e-mail: stephen.wang@monash.edu
}

Cite as: Moriarty, P., Wang, S. J., Eco-Efficiency Indicators for Urban Transport, J. sustain. dev. energy water environ. syst., 3(2), pp 183-195, 2015, DOI: http://dx.doi.org/10.13044/j.sdewes.2015.03.0015

\begin{abstract}
This paper focuses on urban passenger transport eco-efficiency, which can be defined as the production of maximum benefits to society while minimising environmental impacts from urban transport's inputs of energy and materials. Researchers have intensively studied transport's varied environmental impacts, particularly through Life Cycle Assessment; this paper argues that primary transport energy per capita is presently the best measure of impact. Although transport's societal benefits have generally been regarded as self-evident, access to out-of-home activities, not passenger-km, should be considered as the fundamental useful output of an urban transport system, since transport is a derived demand. We argue that access levels are roughly similar in all high-income OECD cities, so that these cities can be ranked on transport eco-efficiency simply on the basis of per capita primary transport energy.
\end{abstract}

\section{KEYWORDS}

Accessibility, Eco-efficiency indicators, Life Cycle Assessment, Urban transport.

\section{INTRODUCTION}

According to the World Business Council for Sustainable Development [1] eco-efficiency "is concerned with creating more value with less impact." Why is eco-efficiency important? We live on a planet with finite resources and a still-growing population. Two pressing problems which are especially relevant for transport are global oil depletion and climate change. We have already passed the peak for conventional oil; unconventional oil reserves, such as deep-water, Arctic or tar sands oil are expensive to extract, and have much greater environmental and input energy costs than conventional oil [2]. Following the European Union, many consider that we must limit the average global temperature rise to no more than $2{ }^{\circ} \mathrm{C}$ above pre-industrial values in order to avert "dangerous anthropological change". Present temperatures are about $0.8{ }^{\circ} \mathrm{C}$ above pre-industrial, and the planet is committed to a further rise of around $0.5{ }^{\circ} \mathrm{C}$ because of the thermal inertia of the oceans [3]. Given the rise in climate extremes that we are increasingly experiencing, Hansen and his colleagues $[4,5]$ have argued that dangerous climate change has already arrived. So the world must urgently obtain the maximum human benefit from, for example, transport, while minimising energy and environmental costs.

The United Nations (UN) estimated that in 2010, 51.4\% of the world's population lived in urban areas, up from $29.4 \%$ in 1950 . By 2050 , the UN project that $67.2 \%$ of the global population will be urban. In many countries of the world, particularly those in the Organization for Economic Cooperation and Development (OECD), the urban share of population is already over $80 \%$ [6]. This paper therefore focuses on urban transport,

\footnotetext{
* Corresponding author
} 
particularly in OECD countries, and seeks to determine the best way to measure the eco-efficiency of urban passenger transport. Cities are already thought to be responsible for $60-80 \%$ of global energy use and greenhouse gases (GHG) emissions. However, urban governments are also leading the way for GHG reductions and environmental sustainability in general [7]. Finding a fair and readily-calculated eco-efficiency indicator for urban passenger transport is thus both important and timely.

The paper examines three main inter-connected research questions:

- What is the best measure for the environmental costs of urban passenger transport?

- What is the best measure for the benefits of urban passenger transport?

- What is therefore the best eco-efficiency indicator for comparisons of passenger transport in different cities?

Section 2 discusses the methods used in the following sections to arrive at a more appropriate measure of eco-efficiency for urban transport. Section 3 addresses research question 1 and so looks at the impacts or costs, of urban passenger transport. Life Cycle Assessment (LCA) studies are reviewed to assess these environmental and resource costs. Our main conclusion is that the most suitable measure for these costs is simply primary transport energy per passenger-km ( $\mathrm{p}-\mathrm{km})$. The chief justification for this measure is that energy, especially liquid fuels, is likely to be in short supply in the coming decades. Additionally, at least for the next few decades, this measure will correlate closely with transport-related $\mathrm{kg}$ carbon dioxide equivalent $\left(\mathrm{CO}_{2 \mathrm{eq}}\right)$ per capita.

Section 4 discusses questions 2 and 3. The benefits of urban transport are usually assumed to be obvious, and measured by mobility, or vehicular $\mathrm{p}-\mathrm{km}$. After discussing the limitations of this assumption, we argue that a better measure of eco-efficiency for urban transport must consider access. We present data supporting the idea that the inverse of annual primary transport energy per capita is the appropriate measure. Cities can simply be ranked on the basis of their per capita primary transport energy. A necessary assumption, for which we provide supporting evidence, is that access levels are roughly similar in all high-income western cities.

\section{METHODOLOGY AND DATA SOURCES}

According to Jasch [8]: "Indicators are used to depict the vast quantity of environmental data of a firm in a comprehensive and concise manner." They allow both a 'comparison of environmental performance over time' and comparison with other organisations-companies, countries or cities. Indicators have been devised to rank all kinds of items of human interest. Countries are ranked according to GDP per capita, and other indices rank the world's universities and liveability of cities. An important one is the two decades old Human Development Index (HDI), devised by the UN Development Programme. As with many other indicators, the HDI amalgamates several different measures into a single number. Ravallion [9] has shown how the way the three dimensions of HDI (health, education, income) are combined is open to serious criticism on ethical grounds. For example, the HDI implicitly values an extra year's life in a wealthy country as having a monetary worth thousands of times its value in the poorest countries. So, on the one hand, a simple number like the HDI (with countries having HDIs from 0 to 1.0) makes public understanding easier, but on the other, it runs the risk of an arbitary and contested weighting of the various components of the index. This paper assesses whether a single number can be used to reliably rank passenger transport in OECD cities on eco-efficiency.

The general approach adopted in this paper is to used published literature, particularly recent national statistical data of OECD countries on both transport and energy, to 
provide supporting evidence for the arguments developed. The paper does not report on any new surveys, or experimental or model results. Further, only urban passenger transport is considered; freight transport in OECD cities typically uses only a small fraction of the energy that passenger travel does, and is not discussed here. The emphasis is on biophysical data as in LCA; social data are not considered.

A search of the published refereed literature shows only a few relevant articles on the eco-efficiency of transport, let alone of urban passenger transport. On the other hand, refereed articles on related topics such as LCA, energy efficiency, and environmental sustainability of different transport modes, fuels, and propulsion systems number in the thousands. Therefore a selection of papers had to be made for evaluation of the environmental costs of transport. The LCA approach was selected because it gives the most comprehensive analysis of transport's various costs. The papers were selected both to illustrate the range of applications relevant to urban passenger transport and the conflicts that can occur between the various environmental costs considered.

The evidence on which conclusions regarding the assumed benefits of urban passenger transport are based derive from transport-related data for various world cities. Where specific urban data is not available, the most recently available national statistical data are used instead. This approach will result in little error, since in the OECD countries examined here, with $80 \%$ or more of the total population urban, per capita travel and income levels will usually be similar for cities and the country overall. The data came mainly from four OECD countries: Australia, Great Britain, Japan and the US. The first three are island nations, which greatly reduces or even eliminates cross-border surface travel. For the US, surface travel across the Canadian and Mexican borders is very small compared to the level of surface travel within the continental US [10]. Two further advantages of using these four countries is that they all have reliable time series statistics and that their transport-relevant statistics (such as urban density or use of public transport) almost span the full range for OECD countries.

\section{ASSESSING THE NEGATIVE IMPACTS OF URBAN PASSENGER TRANSPORT}

A rough idea of the impacts of all forms of transport can be gained from the energy used globally: according to the International Energy Agency (IEA) [11], 27.4\% of final world energy demand was for vehicle operation alone in 2011, up from 23.1\% in 1973. (For the OECD, corresponding values were $32.4 \%$ and $24.7 \%$ ). Such a large energy consumption generates correspondingly large environmental costs. The negative impacts of passenger vehicle operation include energy consumption and emissions of GHGs, chiefly $\mathrm{CO}_{2}$, and various tailpipe pollutants including hydrocarbons, carbon monoxide, and various oxides of nitrogen. The production and maintenance of the vehicles themselves and their supporting infrastructure (chiefly road construction and maintenance) require further inputs of energy and materials, which produce still further $\mathrm{CO}_{2}$ and various pollutants.

\section{LCA for urban transport}

Many researchers have used LCA to investigate and quantify the energy, environmental and resource impacts of transport (e.g. [12]), and to compare these impacts for different transport modes or fuels. Pelletier and Tyedmers [13] describe LCA as follows: "LCA is an ISO-standardized biophysical accounting framework used to (1) inventory the material and energy flows associated with each stage of a product or service "life cycle" and (2) quantify how these flows contribute to a suite of resource use and emissions-related environmental impacts." Energy use and $\mathrm{CO}_{2}$ emissions (sometimes 
$\mathrm{CO}_{2 \text { eq }}$ emissions) are nearly always included, and often air pollutants such as oxides of nitrogen and sulphur and small particulates, as well as the potential for acidification and ozone layer depletion (see, e.g. [14]). From a wider urban passenger transport viewpoint, other impacts to consider might include traffic congestion, traffic collisions and casualties, transport land use, and noise pollution. These impacts are not usually included in LCAs, although Althaus et al. [15] have discussed methods for including traffic noise.

Hawkins et al. [16] compared electric vehicles with conventional vehicles, and demonstrated that although electric vehicles powered by the present European electricity mix would reduce GHGs, the results were very sensitive to assumptions regarding the sources of electricity, as expected. Also, electric vehicles were potentially worse for some impacts, such as human toxicity, and freshwater eco-toxicity and eutrophication. Granovskii et al. [17] compared hydrogen fuel cell vehicles with gasoline vehicles over the full fuel cycle, including all embodied energy inputs. Only if the hydrogen derived from wind or solar energy (but not from natural gas) did hydrogen vehicles give lower $\mathrm{CO}_{2 \mathrm{eq}}$ emissions per vehicle-km (v-km).

Many studies (e.g. [18-21]) from around the world have compared bioethanol and biodiesel with conventional transport fuels. Important findings from these studies were the relevance of location for the results (e.g. the energy and GHG emission costs for bioethanol were both lower in the tropics), and the wide range in energy costs and GHG emissions for biofuels. As for electric vehicles, biofuels were not unambiguously better on all pollution emissions than existing fuels.

LCA calculations for passenger transport show that public transport modes have much lower energy and GHG costs per p-km than private transport-and these costs are lower still for non-motorised modes. These impacts can all be normalised on a p-km basis, which is preferable to a $\mathrm{v}-\mathrm{km}$ basis when comparing different travel modes for vehicles of very different carrying capacity. Typically, public transport modes need less than half the primary energy per $\mathrm{p}-\mathrm{km}$ than that for private transport. (The primary energy for each mode includes the energy lost during, for example, the mining of coal and its conversion to electricity for electric-powered transport, or crude oil production and conversion to petrol or diesel for internal combustion engines.) Using Australian urban data for the mid 1990s, Lenzen [22] showed the variations in primary energy and carbon efficiency between different transport modes and fuels (Table 1).

For the 11 European cities they examined, Newman and Kenworthy [23] found average energy efficiencies of $0.38,0.76$ and $2.0 \mathrm{p}-\mathrm{km}$ per MJ for car, bus and rail respectively. Compared with these European cities, the US (and Australian) bus and rail energy savings are lower because of lower public transport occupancy rates [24], while the savings are higher for Asian public transport, with their very high occupancy rates.

Table 1. Energy and GHG efficiencies for urban Australian travel [22]

\begin{tabular}{ccc}
\hline Transport mode & $\begin{array}{c}\text { Energy efficiency } \\
{[\mathrm{p}-\mathrm{km} / \mathrm{MJ}]}\end{array}$ & $\begin{array}{c}\text { Carbon efficiency } \\
{\left[\mathrm{p}-\mathrm{km} / \mathrm{kgCO}_{2 \mathrm{eq}}\right]}\end{array}$ \\
\hline Tram & 0.71 & 7.7 \\
\hline Bus & 0.48 & 6.7 \\
\hline Train & 0.53 & 5.9 \\
\hline Car-petrol & 0.33 & 4.8 \\
\hline Car-diesel & 0.30 & 4.2 \\
\hline Car-LPG & 0.29 & 4.5 \\
\hline
\end{tabular}




\section{Discussion}

A key problem with calculation of energy costs of different modes of transport is the question of how secondary transport energy (e.g. petrol, diesel, electrical energy) is converted into primary energy. Sometimes it is not clear in the published literature whether primary or secondary energy has been used as the basis for inter-modal comparisons. A more fundamental problem is that different authorities use different methods for such conversions. BP [25] converts electricity from both nuclear and hydro to primary energy by calculating the equivalent amount of fossil fuel energy needed to generate the electricity, assuming 38\% efficiency. The IEA [11] converts nuclear energy on this basis, but converts hydro (and wind and solar electricity) on a 1:1 basis. The IPCC scenarios [26] convert all nuclear, hydro, etc. on a 1:1 basis. Clearly, should electric- or hydrogen-powered transport using electricity from non-fossil fuel sources become important in the future, this issue would need to be resolved.

One difficulty with LCA, in transport as in other areas where LCA is used, is how to interpret the results. How does one balance a decrease in primary energy use against an increase, for example, in emissions of fine particulate matter, as would occur with a change from petrol to diesel road vehicles? For global climate change, the climate forcing effects of various trace gas emissions can be summed using their Global Warming Potential (GWP), and expressed in $\mathrm{CO}_{2}$-equivalent (e.g. $\mathrm{kgCO}_{2 \mathrm{eq}}$ ) terms [27], but such a combined measure is not available for summing the various pollution emissions from transport vehicles, let alone combining these with consumption of non-renewable materials used for vehicle manufacture. If non-tangible items such as noise pollution or transport land use consumption are also considered, the problem is made worse.

In cost benefit analysis, an older approach related to eco-efficiency, all these environmental costs are converted to monetary units and summed. (Urban transport benefits would similarly be expressed in money terms, so that the ratio of benefits to costs could be calculated as a pure number, or as net benefits (i.e. benefits minus costs) in money terms). However, there are many conceptual problems with the cost benefit analysis approach [28], including the thorny problem of valuing nature.

No possible approach which attempts to reduce all urban transport environmental and resource costs to a single number will be fully satisfactory. Although, as mentioned, use of GWP enables all climate change impacts of urban transport to be expressed as a single number (in $\mathrm{kgCO}_{2 \mathrm{eq}}$ ), using such a measure for eco-efficiency of urban transport would present difficulties. It is possible to imagine an urban transport system run entirely on carbon-neutral fuels with close to zero climate change impacts, yet it might still be very inefficient from an energy consumption viewpoint. The opposite case, a zero energy transport system with high GHG emissions, is extremely unlikely to occur in practice.

Why is transport energy consumption so important? A number of researchers have argued that because of depletion of low energy cost fossil fuels, the need to drastically reduce their GHG emissions, and the high cost and/or limited technical potential of alternative energy sources, energy use will be increasingly constrained in future (e.g. [2, 29-32]). This conclusion is supported by the analyses of both Myhrvold and Caldeira [33] and van Vuuren and Stehfest [34], who used energy modelling to argue that neither energy alternatives (renewable energy and nuclear power), nor attempts to reduce $\mathrm{CO}_{2}$ emissions from fossil fuels by carbon capture and sequestration, or even by efficiency improvements, will be significant by 2050 .

Usón et al. [12] have shown that the embodied energy costs for car manufacture in the European Union are typically only $15-20 \%$ of the car fuel energy costs, so that operating energy costs of vehicles dominate transport's total energy use. Transport's primary energy consumption for vehicle operation only has therefore been selected here as a 
useful single measure of transport's impact. At present, GHG emissions are closely correlated with transport primary energy use, because over $96 \%$ of all transport fuel is still fossil fuel-based. Even urban electric public transport is still largely fossil fuel based (in the OECD countries, 62\% of electricity was from fossil fuel sources in 2011) [25]. Hence energy use can also serve as a proxy for climate change impact. And as just discussed, this correlation is unlikely to change much in the coming decades, because the alternatives to oil, including biomass liquid fuels, have $\mathrm{CO}_{2 \mathrm{eq}}$ emissions per MJ of primary transport energy that may not differ much from oil-based fuels [35]. It might even be possible to convert pollutant emissions to energy terms as well, by considering the energy costs of effective pollution control devices [36]. More controversially, the late Richard Douthwaite [37] has suggested that, given future energy scarcity, money could be backed by energy, which would further strengthen the case for a simple energy indicator.

Finally, the wider impacts mentioned (traffic congestion, traffic collisions and casualties, land use, and noise pollution) tend to be more severe for private car travel than for public or non-motorised transport on a p-km basis. Since these latter modes are also more energy and GHG efficient, no trade-offs for different impacts are needed. In summary, the best measure for urban transport environmental and resource costs is presently primary transport energy per $\mathrm{p}-\mathrm{km}$, a measure that should be accurate enough at least for several decades to come.

\section{ASSESSING THE ASSUMED BENEFITS OF URBAN PASSENGER TRANSPORT}

Transport eco-efficiency, like any other efficiency measure, is maximised by maximising the benefits relevant to humans while minimising the attendant costs. The benefits of urban passenger transport have usually been regarded as self-evident, and assumed to consist solely of mobility, as measured by p-km. Often, mobility is restricted to vehicular $\mathrm{p}-\mathrm{km}$, omitting travel on foot or by bicycle. While mobility is thus easy to define, its relevance is at issue. The usually implicit assumption is that higher levels of mobility provide greater benefits than lower levels.

If benefits derived from urban transport were simply equated with $\mathrm{p}-\mathrm{km}$, whether vehicular only or all-modes, then further consideration would be unnecessary; the previous section has already discussed the costs or impacts of urban travel per p-km. Eco-efficiency could then simply be measured as p-km delivered per unit of primary transport energy. But, as discussed by Litman [38], there are definite limits to the efficacy of this measure of eco-efficiency, particularly in comparison with the magnitude of the oil and GHG reductions needed.

\section{Accessibility: the real benefit of urban transport}

The basic question to ask is: What is urban passenger travel meant to achieve? As is well-known, passenger transport is a derived demand [39]: travellers must outlay both money and time to reach desired destinations. Given that it is a derived demand, it is relevant to ask whether greater levels of urban mobility provide greater benefits. The derived demand that travellers seek is accessibility, which can be defined as the ease with which urban residents can reach opportunities (e.g. jobs and shops), or the ease with which the residents themselves can be reached. In some cases, it can even mean access to the services provided at these destinations. Depending on the particular city, and usually also on the location within that city (e.g. inner vs outer suburbs), the average trip length to typical destinations such as workplaces or shopping centres can vary greatly. 
Halden [40] has stated that "accessibility is an attribute of people and goods rather than transport modes or service provision", and stressed that "The main problem with the concept of mobility, and the reason why it has proved to be a controversial aim, is that it is difficult to say whether more or less travel is preferable, and whether more or fewer trips are better." He goes on to add more specifically that "despite accessibility being a function of mobility, improved mobility does not always lead to improved accessibility." Both travel times and cost are important for accessibility. Iacono et al. [41], for example, have derived urban accessibility measures for non-motorised transport in terms of distance, time and cost. Given that distance, time, cost, (and for non-motorised transport, the physical effort involved) are all important for assessing accessibility, a simple quantitative definition is not possible.

That more mobility is not always better than less can be readily seen from the example of the urban journey to work. Newman and Kenworthy [23] have tabulated the average commuting trip lengths for 32 world cities for the year 1990. The average commute for European cities was only $10 \mathrm{~km}$, compared with $15 \mathrm{~km}$ for US cities. For Houston, the average commute was $19.1 \mathrm{~km}$, over twice that for London at $9.2 \mathrm{~km}$. This increased commuting trip length is better seen as a disbenefit or cost rather than a benefit. Although quantitative data for other trip types is not available, it seems unlikely that the lower personal mobility of European city residents limits their ability to satisfy their needs for education, shopping, meeting friends, or entertainment. A further point is that at least some travel is simply for the sake of travel, and not for access purposes [39].

In general, research has shown that increasing urban density will reduce the average distance for work, shopping, and other trip types [23, 42]. But even holding average residential density fixed, trip distances can be reduced by a better mix of residences, workplaces, shops, etc. Further, policy makers can and do intervene to reduce the need for travel in the name of equity [43]. They can, for example, provide services such as public libraries, primary schools or health care clinics in areas of a city that presently lack such services.

Further, urban residents can sometimes obtain many desired services, whether provided by the public or private sector, without requiring physical travel to the service provider location. Instead, these services can often be accessed by telephone, or increasingly, online. An example would be providing details online for collecting unemployment or other government benefits, as an alternative to physically visiting the government offices. Even more ambitiously, many people are now working at home (telecommuting) or studying or shopping online.

\section{OECD cities have similar access levels}

The assumption made in this paper is that, at least for OECD cities, accessibility is roughly the same for all cities, regardless of their per capita travel levels, or at the least, that it cannot simply be assumed that accessibility is better in some cities than others. But such an assumption is open to the counterarguments that in lower mobility cities, mobility is restricted by the time and effort to make extra trips, or that many residents might simply not be able to afford higher mobility levels. We consider the travel time and cost counterarguments in turn.

The more compact cities of Europe and Asia might be more accessible in distance terms than US cities, but trip times could be longer. To check this possibility, we again used the data in Newman and Kenworthy [23] to calculate average total annual travel times per capita for the US, European, Canadian, Australian, and Asian city groups. The Asian group included a number of low-income cities; hence average travel times were calculated using only Hong Kong, Singapore and Tokyo. Table 2 gives the results. 
Table 2. Per capita annual travel times by region/country, 1990 [23]

\begin{tabular}{cccccc}
\hline & US & Canada & Australia & Europe & Asia \\
\hline Car travel time [hrs] & 314 & 233 & 237 & 184 & 86 \\
\hline $\begin{array}{c}\text { Public transport travel } \\
\text { time [hrs] }\end{array}$ & 19 & 43 & 31 & 56 & 131 \\
\hline Total travel time [hrs] & 333 & 276 & 268 & 240 & 237 \\
\hline
\end{tabular}

The extent of non-motorised travel is unknown. Even assuming that residents of European, Canadian and Australian cities spent 50 hours, and Asian cities 100 hours more per year, for non-motorised modes (roughly $0.5 \mathrm{~km}$ and $1.0 \mathrm{~km}$ per day respectively) than in US cities, all would still have similar or less total travel time compared with for the US.

It is also possible to argue that residents of lower income cities have lower mobility levels because they cannot afford as much urban vehicular travel as they would like. If true, then $\mathrm{p}-\mathrm{km}$ might still be the best measure of transport benefit. In the low-income cities of industrialising countries vehicular travel is very likely constrained by low incomes, but, we will argue, such is not the case for cities above a certain average income level. Examination of urban travel trends and patterns in various OECD cities supports this argument. First, in Australia's large cities, inner area residents have much higher incomes than those living further from the city centre, yet their car ownership and per capita vehicular travel levels are smaller [44]. While it is true that road traffic is more congested in the inner areas of these cities, higher income people choose to live there, although they could live further out, and enjoy the higher vehicular mobility (in terms of per capita $\mathrm{p}-\mathrm{km}$ ) possible with outer suburban living.

A second piece of evidence for the unimportance of income is the recent drop in per capita surface travel observed in Japan [45], the US [46], Australia [47], and several other OECD countries [48]. Importantly, this drop seems to have occurred several years before the current global financial crisis. Where urban data is also available, the same pattern is observed in many OECD cities. In all of Australia's eight capital cities (which include all five of its one-million plus cities), per capita vehicular p-km has fallen since 2004. In Melbourne, for example, car travel dropped from 12,410 p-km in 2004 to 11,300 in 2010, or about $9 \%$ [47, 49]. Yet real per capita incomes have continued to rise [44]. Similarly, in London, per capita disposable incomes rose steadily over the period 1997-2010 [50], but absolute vehicular travel on major roads in London fell by $8.6 \%$ between 2001 and 2011 [51]. We conclude that in the cities of the OECD at least, income is no longer a constraint on urban passenger travel.

\section{Discussion}

If it is accepted that access can be at least maintained at lower levels of vehicular mobility (and transport energy use), then OECD cities differ greatly on transport accessibility per p-km. What factors are responsible for this? Cities with lower levels of vehicular mobility tend to have higher urban densities (see, for example [23]). The densely-populated high-income Asian cities, and to a lesser extent, European cities, have higher levels of more energy-efficient public transport and non-motorised trip-making than North American or Australian cities, resulting in much lower levels of transport energy per capita. However, they also tend to have less road space per capita, less central city parking spaces per 1,000 workers there, and lower average road travel speeds. More recent data showed similar findings [42]. Table 3 illustrates these differences with data from two cities that are near the extremes for the various parameters listed: Houston and 
Tokyo. In an earlier paper, it was argued that the main reason why higher density cities have less travel is because high density lowers the convenience of car travel, particularly by lowering average car speeds [52]. It follows that transport policies which reduce car travel convenience (e.g. by reducing speed limits or central city parking spaces) would cut travel without the need for density changes.

Further, the level of personal travel in cities has historically depended strongly on which mode-private car, the various forms of urban public transport, or non-motorised travel-was the dominant form of transport [53]. Per capita vehicular p-km in the present car era can be several times that of the public transport era. Any shift back to public and non-motorised travel would lead to decreased mobility, because the change in dominant mode would over time radically change the location of workplaces and services, and thus trip-making patterns. We stress that changes of this magnitude will require continued and innovative interactions between novel transport system designs and users, that is, the travelling public [54].

The conclusion is that residents of the high-income OECD cities enjoy roughly similar accessibility benefits, regardless of the large differences in their vehicular mobility levels. This is not to argue that any city enjoys perfect accessibility, whatever that term might mean. In other words, we have implicitly argued here that access per $\mathrm{p}-\mathrm{km}$ is higher in these lower mobility cities, because of different land use patterns and transport policies. What seems to happen is that cities that cannot readily accommodate more private car mobility adjust both by providing more extensive public transport, walking and cycling more, and by having a better spatial distribution of residences and workplaces, shops etc. If this is true, then the eco-efficiency of urban transport for a given city can be simply defined as follows: total urban population divided by total urban passenger transport energy, where transport energy is understood as operating energy only, measured in primary energy terms. This simple indicator will allow easy ranking of cities.

Table 3. Transport-related parameters for Houston and Tokyo, 1990 [23]

\begin{tabular}{ccc}
\hline & Houston & Tokyo \\
\hline Urban density [persons/hectare] & 9.5 & 71.0 \\
\hline Road provision [metres/capita] & 11.7 & 3.9 \\
\hline CBD parking spaces/1000 jobs & 612 & 43 \\
\hline Average car speed [km/h] & 61.2 & 24.4 \\
\hline Transit work trips [\%] & 4.1 & 48.9 \\
\hline Walk/cycle work trips [\%] & 2.6 & 21.7 \\
\hline Total annual vehicular [p-km/capita] & 19,220 & 8,680 \\
\hline Total annual vehicular [MJ/capita] & 71,620 & 18,240 \\
\hline
\end{tabular}

A further important advantage of using this measure rather than $\mathrm{p}-\mathrm{km}$ per unit of transport energy, is that it avoids the problem of energy (and transport) rebound. Energy rebound occurs for several reasons [55], but the one relevant to transport eco-efficiency is that any decrease in energy per p-km (by improving vehicle fuel efficiency, for example), by lowering the monetary cost of urban travel, encourages more travel to be undertaken. The nature of the two key problems facing transport, oil depletion and climate change, demand, not just reductions per p-km, but absolute reductions in both energy and GHG emissions. 


\section{CONCLUSION}

Urban passenger transport eco-efficiency can be defined as the production of maximum benefits to society while minimising environmental impacts from inputs of energy and materials. Because of global oil depletion and still rising GHGs from transport, there is an urgent need to greatly improve this eco-efficiency of urban passenger transport. Such improvements can come from either reducing the environmental and resource impacts that urban passenger travel generates, or the volume of vehicular passenger travel itself, while retaining the benefits (in terms of access to desired destinations) that such travel is meant to provide. The use of an eco-efficiency indicator for urban transport enables cities to track their progress toward sustainability over time, and to compare themselves with other cities and with benchmarks.

The passenger transport task is usually taken as a given. However, this paper has shown that levels of personal vehicular travel (in $\mathrm{p}-\mathrm{km}$ per capita), even for cities with comparable standards of living, can vary greatly from city to city, depending on such factors as urban land use and especially transport policies. Access to out-of-home activities, not $\mathrm{p}$-km per capita, should be considered as the fundamental useful output of an urban transport system, since transport is a derived demand. The level of personal travel in cities has historically depended strongly on which mode-private car, the various forms of urban public transport, or non-motorised travel was the dominant form of transport. We have argued that accessibility levels in high-income OECD cities are much the same, so that lower mobility cities have higher levels of access per $\mathrm{p}-\mathrm{km}$.

We conclude that the best way of ranking cities on passenger transport eco-efficiency is simply on the basis of per capita primary transport energy, with transport eco-efficiency measured as urban population divided by total urban transport energy.

\section{NOMENCLATURE}

\section{Abbreviations}

IPCC Intergovernmental Panel on Climate Change

ISO International Organization for Standardization

\section{ACKNOWLEDGEMENT}

Dr Stephen Jia Wang (corresponding author) acknowledges that this research is supported by Microsoft Research Asia as part of the funded project: Intelligent Sustainable Navigation Services (ISUNS), contract number FY14-RES-THEME-008.

\section{REFERENCES}

1. World Business Council for Sustainable Development (WBCSD), Eco-efficiency: Creating More Value with Less Impact, WBCSD, Geneva, Switzerland 2000.

2. Heinberg, R., Snake Oil: How Fracking's False Promise of Plenty Imperils Our Future, Post Carbon Institute, Santa Rosa, CA, 2013.

3. Pierce, D. W., Barnett, T. P. and Gleckler, P. J., Ocean Circulations, Heat Budgets, and Future Commitment to Climate Change, Annu. Rev. Environ. Resour., Vol. 36, pp 27-43, 2011, http://dx.doi.org/10.1146/annurev-environ-022610-112928

4. Hansen, J., Sato, M., Kharecha, P. and von Schuckmann, K., Earth's Energy Imbalance and Implications, Atmos. Chem. Phys., Vol. 11, pp 13421-13449, 2011, http://dx.doi.org/10.5194/acp-11-13421-2011

5. Hansen, J., Kharecha, P. and Sato, M., Climate Forcing Growth Rates: Doubling Down on our Faustian Bargain, Environ. Res. Lett., Vol. 8, 011006 (9pp), 2013, http://iopscience.iop.org/1748-9326/8/1/011006, [Accessed: 18-March-2014] 
6. United Nations (UN), World Urbanization Prospects: The 2011 Revision, 2012, http://esa.un.org/unpd/wup/index.htm, [Accessed: 18-March-2014]

7. Hallegatte, S. and Corfee-Morlot, J., Understanding Climate Change Impacts, Vulnerability and Adaptation at City Scale: An Introduction, Clim. Change, Vol. 104, pp 1-12, 2011, http://dx.doi.org/10.1007/s10584-010-9981-8

8. Jasch, C., Environmental Performance Evaluation and Indicators, J. Cleaner Prod., Vol. 8, pp 79-88, 2000, http://dx.doi.org/10.1016/S0959-6526(99)00235-8

9. Ravallion, M., The Human Development Index: A Response to Klugman, Rodriguez and Choi, J. Econ. Inequal., Vol. 9, pp 475-478, 2011, http://dx.doi.org/10.1007/s10888-011-9193-0

10. Bureau of Transportation Statistics (BTS), 2014 Pocket Guide to Transportation, BTS, Washington, DC, 2014.

11. International Energy Agency (IEA), Key World Energy Statistics 2013, IEA/OECD, Paris, 2013.

12. Usón, A. A., Capilla, A. V., Bribián, I. Z., Scarpellini, S. and Sastresa, E. L., Energy Efficiency in Transport and Mobility from an Eco-efficiency Viewpoint, Energy, Vol. 36, pp 1916-1923, 2011, http://dx.doi.org/10.1016/j.energy.2010.05.002

13. Pelletier, N. and Tyedmers, P., An Ecological Economic Critique of the Use of Market Information in Life Cycle Assessment Research, J. Ind. Ecol., Vol. 15, No. 3, pp 342-355, 2011, http://dx.doi.org/10.1111/j.1530-9290.2011.00337.x

14. Cherubini, F. and Strømman, A. H., Life Cycle Assessment of Bioenergy Systems: State of the Art and Future Challenges, Bioresour. Technol., Vol. 102, pp 437-451, 2011, http://dx.doi.org/10.1016/j.biortech.2010.08.010

15. Althaus, H-J., Peter de Haan, P. and Scholz, R. W., Traffic Noise in LCA: Part 2: Analysis of Existing Methods and Proposition of a New Framework for Consistent, Context-Sensitive LCI Modeling of Road Transport Noise Emission, Int. J. Life Cycle Assess., Vol. 14, pp 676-686, 2009, http://dx.doi.org/10.1007/s11367-009-0117-1

16. Hawkins, T. R., Singh, B., Majeau-Bettez, G. and Strømman, A. H., Comparative Environmental Life Cycle Assessment of Conventional and Electric Vehicles, J. Ind. Ecol., Vol. 17, No. 1, pp 53-64, 2012, http://dx.doi.org/10.1111/j.1530-9290.2012.00532.x

17. Granovskii, M., Dincer, I. and Rosen, M. A., Life Cycle Assessment of Hydrogen Fuel Cell and Gasoline Vehicles, Int. J. Hydrog. Energy, Vol. 31, pp 337-352, 2006, http://dx.doi.org/10.1016/j.ijhydene.2005.10.004

18. Wang, M., Han, J., Dunn, J. B., Cai, H. and Elgowainy, A., Well-to-Wheels Energy Use and Greenhouse Gas Emissions of Ethanol from Corn, Sugarcane and Cellulosic Biomass for US Use, Environ. Res. Lett., Vol. 7 (045905) (13pp), 2012, http://dx.doi.org/doi:10.1088/1748-9326/7/4/045905

19. Niemistö, J., Saavalainen, P., Pongrácz, E. and Keiski, R. L., Biobutanol as a Potential Sustainable Biofuel - Assessment of Lignocellulosic and Waste-based Feedstocks, $J$. Sustain. Development of Energy, Water \& Environ. Sys., Vol. 1, No. 2, pp 58-77, 2013, http://dx.doi.org/10.13044/j.sdewes.2013.01.0005

20. Nanaki, E. A. and Koroneos, C. J., Comparative LCA of the Use of Biodiesel, Diesel and Gasoline for Transportation, J. Cleaner Prod., Vol. 20, pp 14-19, 2012, http://dx.doi.org/10.1016/j.jclepro.2011.07.026

21. von Blottnitz, H. and Curran, M. A., A Review of Assessments Conducted on Bio-Ethanol as a Transportation Fuel from a Net Energy, Greenhouse Gas, and Environmental Life Cycle Perspective, J. Cleaner Prod., Vol. 15, pp 607-619, 2007, http://dx.doi.org/10.1016/j.jclepro.2006.03.002

22. Lenzen, M., Total Requirements of Energy and Greenhouse Gases for Australian Transport, Transp. Res. Part D, Vol. 4, pp 265-290, 1999, http://dx.doi.org/10.1016/S1361-9209(99)00009-7 
23. Newman, P. and Kenworthy, J., Sustainability and Cities: Overcoming Automobile Dependence, Island Press, Washington, DC, 1999.

24. Davis, S. C., Diegel, S. W. and Boundy, R. G., Transportation Energy Data Book: Edition 32-2013, ORNL, http://cta.ornl.gov/data/tedb32/Edition32_Full_Doc.pdf, 2013, [Accessed: 06-November-2013]

25. BP, BP Statistical Review of World Energy 2014, BP, London, 2014.

26. van Vuuren, D. P., Edmonds, J., Kainuma, M., Riahi, K., Thomson, A., et al., The Representative Concentration Pathways: An Overview, Clim. Change, Vol. 109, pp 5-31, 2011, http://dx.doi.org/10.1007/s10584-011-0148-z

27. Intergovernmental Panel on Climate Change (IPCC), Climate Change 2013: The Physical Science Basis. Technical Summary, http://www.climatechange2013.org/images/report/WG1AR5_TS_FINAL.pdf, 2013, [Accessed: 20-February-2014]

28. Beukers, E., Bertolini, L. and Brömmelstroet, M. T., Why Cost Benefit Analysis is Perceived as a Problematic Tool for Assessment of Transport Plans: A Process Perspective, Transp. Res. Pt A, Vol. 46, pp 68-78, 2012.

29. Höök, M. and Tang, X., Depletion of Fossil Fuels and Anthropogenic Climate Change-A Review, Energy Policy, Vol. 52, pp 797-809, 2013, http://dx.doi.org/10.1016/j.enpol.2012.10.046

30. Ward, J. D., Mohr, S. H., Myers, B. R. and Nel, W. P., High Estimates of Supply Constrained Emissions Scenarios for Long-Term Climate Risk Assessment, Energy Policy, Vol. 51, pp 598-604, 2012, http://dx.doi.org/10.1016/j.enpol.2012.09.003

31. Moriarty, P. and Honnery, D., What Energy Levels Can the Earth Sustain?, Energy Policy, Vol. 37, pp 2469-2474, 2009, http://dx.doi.org/10.1016/j.enpol.2009.03.006

32. Moriarty, P. and Honnery, D., Preparing for a Low Energy Future, Futures, Vol. 44, pp 883-892, 2012, http://dx.doi.org/10.1016/j.futures.2012.08.002

33. Myhrvold, N. P. and Caldeira, K., Greenhouse Gases, Climate Change and the Transition from Coal to Low-Carbon Electricity, Environ. Res. Lett., Vol. 7, 014019 (8pp), 2012, http://dx.doi.org/10.1088/1748-9326/7/1/014019

34. van Vuuren, D. P. and Stehfest, E., If Climate Action Becomes Urgent: The Importance of Response Times for Various Climate Strategies, Clim. Change, Vol. 121, pp 473-486, 2013, http://dx.doi.org/10.1007/s10584-013-0769-5

35. Pimentel, D. and Burgess, M., Biofuel Production Using Food, Environ. Dev. Sustain. Vol. 16, pp 1-3, 2014, http://dx.doi.org/10.1007/s10668-013-9505-6

36. Moriarty, P. and Honnery, D., Energy Efficiency: Lessons from Transport, Energy Policy, Vol. 46, pp 1-3, 2012, http://dx.doi.org/10.1016/j.enpol.2012.04.056

37. Douthwaite, R., Degrowth and the supply of money in an energy-scarce world, Ecol. Econ., Vol. 84, pp 187-193, 2012, http://dx.doi.org/10.1016/j.ecolecon.2011.03.020

38. Litman, T., Comprehensive Evaluation of Energy Conservation and Emission Reduction Policies, Transp. Res. Pt A, Vol. 47, pp 153-166, 2013, http://dx.doi.org/10.1016/j.tra.2012.10.022

39. Cao, X., Mokhtarian, P. L. and Handy, S. L., No Particular Place to Go: An Empirical Analysis of Travel for the Sake of Travel, Environ. \& Behavior, Vol. 41, pp 233-257, 2009, http://dx.doi.org/10.1177/0013916507310318

40. Halden, D., The Use and Abuse of Accessibility Measures in UK Passenger Transport Planning, Res. Transp. Business \& Mgt, Vol. 2, pp 12-19, 2011, http://dx.doi.org/10.1016/j.rtbm.2011.05.001

41. Iacono, M., Krizek, K. J. and El-Geneidy, A., Measuring Non-Motorized Accessibility: Issues, Alternatives, and Execution, J. Transp. Geogr., Vol. 18, pp 133-140, 2010, http://dx.doi.org/10.1016/j.jtrangeo.2009.02.002 
42. Kenworthy, J. and Inbakaran, C., Differences in Transport and Land Use in Thirteen Comparable Australian, American, Canadian and European Cities between 1995/6 to 2005/6 and Their Implications for More Sustainable Transport, ATRF Proceedings, 28-30 September, Adelaide, Australia, 2011, http://www.worldtransitresearch.info/cgi/viewcontent.cgi?article $=5608 \&$ context=res earch, [Accessed: 16-January-2013]

43. Preston, J. and Rajé, F., Accessibility, Mobility and Transport-Related Social Exclusion, J. Transp. Geogr., Vol. 15, pp 151-160, 2007, http://dx.doi.org/10.1016/j.jtrangeo.2006.05.002

44. Australian Bureau of Statistics (ABS), Census Results CD-rom, 2011, Also earlier census results.

45. Statistics Bureau Japan, Japan Statistical Yearbook 2014, Statistics Bureau, Tokyo, 2014, http://www.stat.go.jp/english/data/nenkan/index.htm, [Accessed; 11-February-2014]

46. U.S. Department of Transportation, Traffic Volume Trends: January 2013, Federal Highway Administration, 2013, http://www.fhwa.dot.gov/policyinformation/travel_monitoring/13jantvt/13jantvt.pdf, Also earlier editions, [Accessed: 12-April-2013]

47. Bureau of Infrastructure, Transport and Regional Economics (BITRE), Australian Infrastructure Statistics Yearbook 2011, Department of Infrastructure and Transport, Canberra ACT, Australia, 2011.

48. Millard-Ball, A. and Schipper, L., Are We Reaching Peak Travel? Trends in Passenger Transport in Eight Industrialized Countries, Transp. Rev., Vol. 31, No. 3, pp 357-378, 2011, http://dx.doi.org/10.1080/01441647.2010.518291

49. Bureau of Infrastructure, Transport and Regional Economics (BITRE), Traffic Growth in Australia, Report 127, Department of Infrastructure and Transport, Canberra ACT, Australia, 2012.

50. Office for National Statistics, Household Disposable Income Across the UK, 2010, 2012, http://www.ons.gov.uk/ons/dcp171776_270749.pdf, [Accessed: 09-February-2014]

51. UK National Statistics, Region and Country Profiles: Key Statistics, 2012, http://www.ons.gov.uk/ons/taxonomy/index.html?nscl=Travel+and+Transport, [Accessed: 09-February-2014]

52. Moriarty, P. and Honnery, D., Greening Passenger Transport: A Review, J. Cleaner Production, Vol. 54, pp 14-22, 2013, http://dx.doi.org/10.1016/j.jclepro.2013.04.008

53. Moriarty, P. and Honnery, D., Rise and Fall of the Carbon Civilisation, Springer, London, UK, 2011, http://dx.doi.org/10.1007/978-1-84996-483-8

54. Wang, S. J., Fields Interaction Design (FID): The Answer to Ubiquitous Computing Supported Environments in the Post-Information Age, Homa \& Sekey Books, Paramus, NJ, 2013.

55. Druckman, A., Chitnis, M., Sorrell, S. and Jackson, T., Missing Carbon Reductions? Exploring Rebound and Backfire Effects in UK Households, Energy Policy, Vol. 39, pp 3572-3581, 2011, http://dx.doi.org/10.1016/j.enpol.2011.03.058 